\title{
Light Navigation Around the Republic of Kalmikia, RUSSIA
}

\begin{abstract}
Kalmykia is a unique region in the Russian Federation as its identity dramatically different from other regions of the European part of Russia. It is an intercultural westernmost part of Russia, which professes Buddhism; its traditions are tightly connected with its religion creating a nonrecurring environment.

"Navigation system of Kalmykia, Russia", tries to solve an existing problem of promoting the cultural heritage of the Republic both within Russia and abroad. One of the goals of this project is to attract people to Kalmykia, introduce them to the Buddhist culture and boost the development of the whole region, as Kalmykia is not yet a very well known place, despite its outstanding beauty.

Based on a thorough research of Buddhist philosophy, traditions and culture the concept of a special navigation system was developed. This system crosslinks traditions, legends and beliefs with modern technologies. The concept of a tourist navigation system in the form of a network of laser beams with the possible application of special textiles and reflective elements was proposed. This connects the design with modern technologies and improves communication between cultural researchers and technical developers.

Tourists will find a special light net with beacons near every place of importance. Furthermore, this solution resulted in the creation of a website.
\end{abstract}

Keywords: light, integration, Buddhism philosophy, concept of design

\section{Introduction}

Kalmykia is a unique region in the Russian Federation as its identity dramatically different from other regions of the European part of Russia. The Kalmyk people or Kalmyks is the name given to the Oirats, western Mongols in Russia, whose ancestors migrated from Dzhungaria in 1607. They created the Kalmyk Khanate in 1630-1724 in Russia's North Caucasus territory. Today they form a majority in the autonomous Republic of Kalmykia on the western shore of the Caspian Sea. Kalmykia has Europe's only Buddhist government. The republic is located in the south-western part of European Russia and borders, clockwise, with Volgograd Oblast in the northwest and north, Astrakhan Oblast in the north and east, the Republic of Dagestan in the south, Stavropol Krai in the southwest, and with Rostov Oblast in the west. It is washed by the Caspian Sea in the southeast. Figure 1 shows a location the Republic of Kalmykia in Russia.

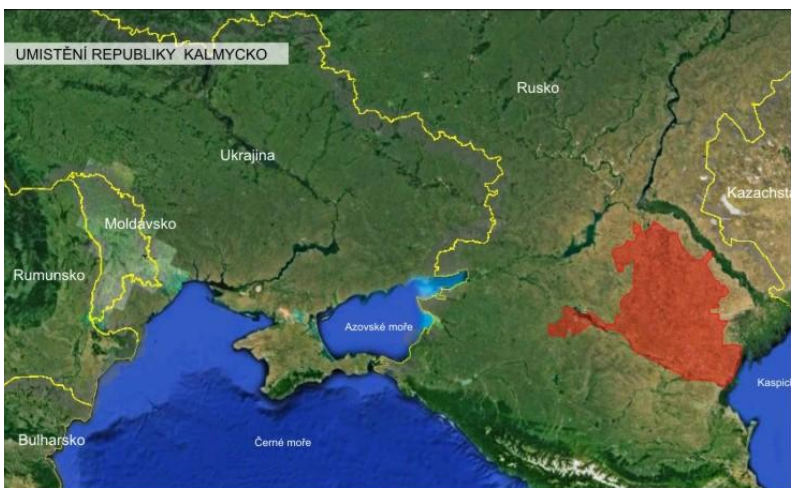

Fig.1. Location the Republic of Kalmykia in Russia

Nevertheless the research showed that the popularity of Kalmykia is very low [1]. Kalmykia can expose unique natural monuments, reserve locations, rich flora and rare birds. It is the route of the Great Silk Road, dwelling of Khazars, place of the Golden Horde cities and remains of Sarai Berke, the second capital of the Golden Horde. The great Historical Crossroads, the center of the Eurasian continent is located here. Advantageous geographical location of the republic is favorable to the development of tourism. The climate of the republic is continental with a moderate little snowy winter and hot summers. The bathing season starts on many water reservoirs already in May. Attractions location is showed on the map Republic of Kalmykia in the Figure 2.

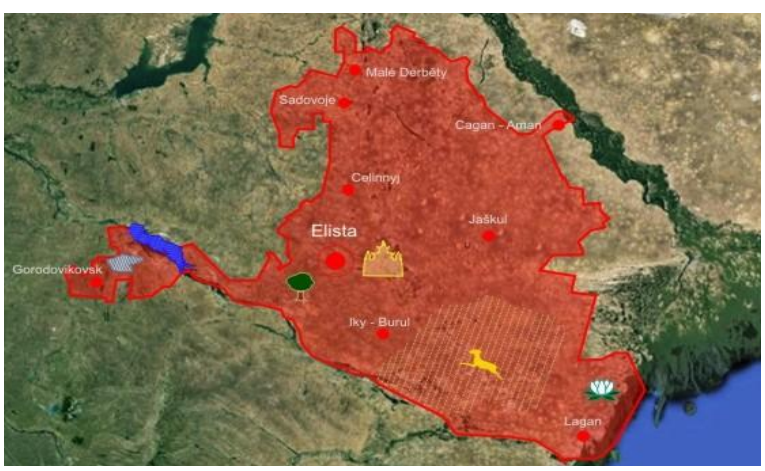

Fig.2. Location attractions on the map Republic of Kalmykia

The aim of this work is to attract people to Kalmykia and introduce them to the sights and traditions of the Republic and also to tell about its Buddhist culture. The concept of the project is a legend, which is based on the philosophy of Buddhism. According to this philosophy, one must develop comprehensively, both outside and inside. It longs for the "ideal" knowledge of pure existence, one's body, physical culture and ancestor worship. Each Kalmykia monument is a source of energy that comes and helps it achieve that ideal. This energy is spread out in all directions, it crosses and creates a strange 'routing network.

\section{Concept of design}

A visitor of Kalmykia has the opportunity to walk this "way", a way that was once walked by Ojrati since the days of paganism to Buddhist. This path leads across the country and ends in its center in ELISTA. The essence of paganism is the worship of nature, its elements, animals, humans and plants. Therefore the journey starts with exploring nature, its diversity and therapeutic abilities. All of the memorable places in the Republic are tied to the pagan believes of the Kalmyk people and help a human to understand human nature and find unity with it.

A person is ready to recognize a new religious movement that appeared here - Buddhism. Before that 
person sights of the capital city, Elista, open. The goal of Buddhism is to develop human resources, knowledge of their own thoughts, intellect, full enlightenment, liberation of the human mind from the constraints and obstacles.

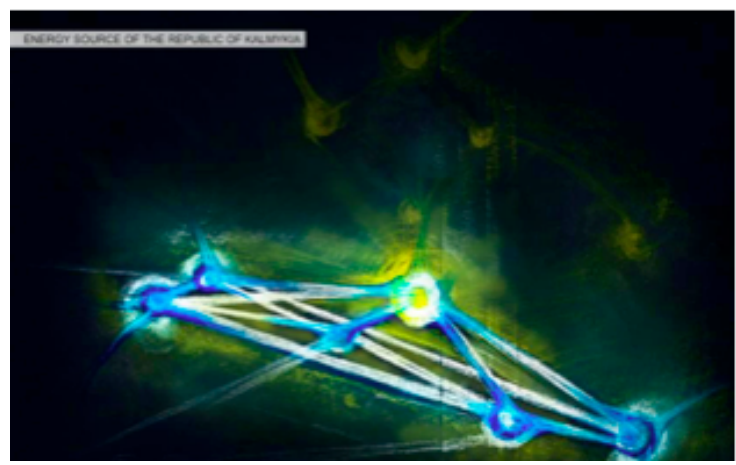

Fig.3. Schema of energy source Republic of Kalmykia

Buddhist temple Churul is the main source of solar energy that spreads throughout Kalmykia. Its particles combine to form one solar structures and that structure gives impetus to the further development of the country. Figure 3 shows energy source in Republic of Kalmykia and Figure 4 shows energy source in city of Elista.

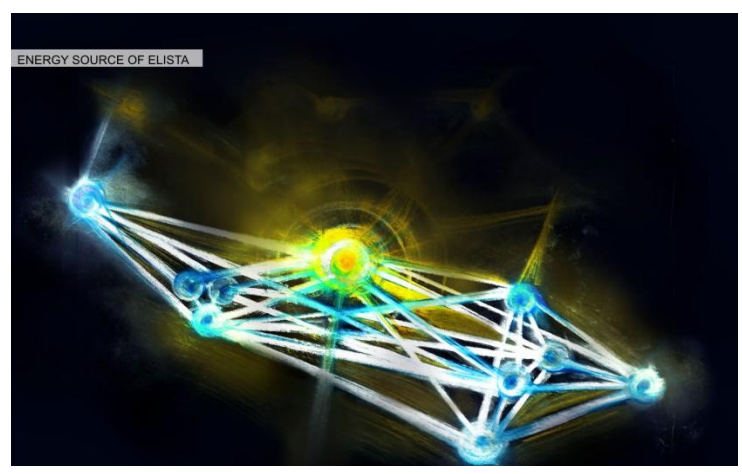

Fig.4. Schema of energy source city of Elista

The sun's rays symbolize "white roads" which interconnect sacred places and together they form an imaginary grid as a guide for travelers from one monument to another. Figure 5 shows navigation around Republic of Kalmykia.

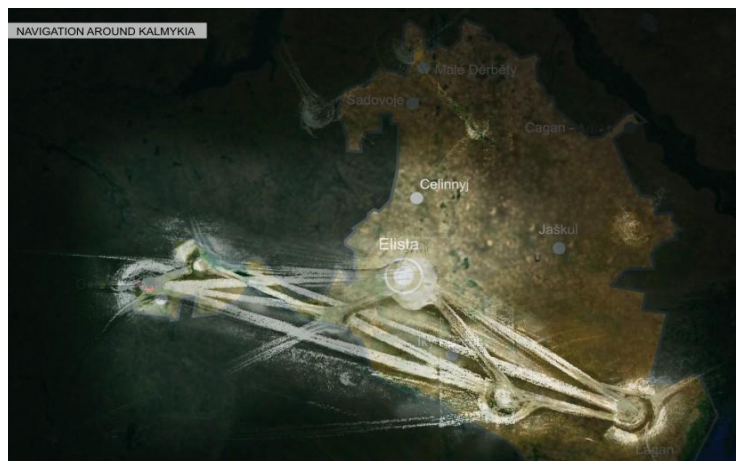

Fig.5. Schema navigation around Republic of Kalmykia
The path of self-knowledge begins with the Golden Gates. This place is a sort of transition from pagan religion to Buddhism and symbolizes spiritual cleansing. Winding trail of white stone, "white road", symbolizes the path to perfection of knowledge of being. I passed all the sights, the man approaches perfection. When one bows to ancestors, pays tribute to the Ojrat history. The most sacred place of Kalmykia reveals itself, the Buddhist temple. Figure 6 shows navigation around city of Elista:

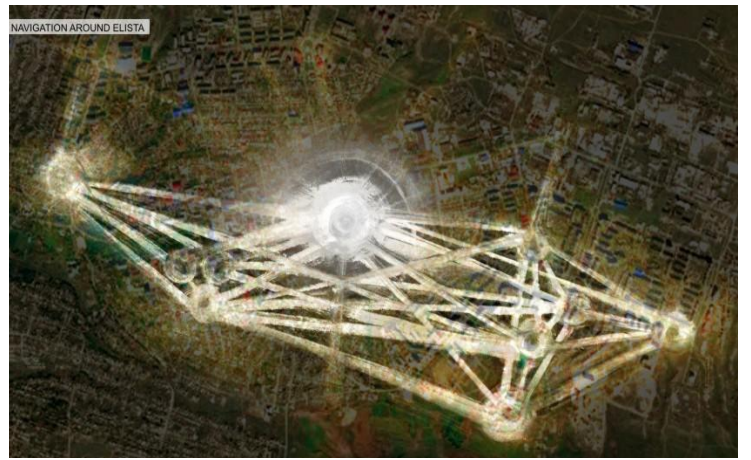

Fig.6. Schema navigation around city of Elista

\section{The solution of design}

Road lighting increase the safety in the road thanks to so called sight guide. Fittings put up above the road gives the driver additional information about turn's direction of road. Using different type of lighting should mark access roads and exits from main road. We can achieve this for instance by putting up the fittings in different heights or by install different light sources inside the fittings. Thanks to this solutions driver knows what is going on the road. The intention was to place "beacons" on the territory of Kalmykia, which would create a light net above the city. The idea of creating a "beacon" was based on the legend of the sacred stone "Cintamani», which spreads light over long distances. Figure 7 shows lighthouse in the city of Elista.

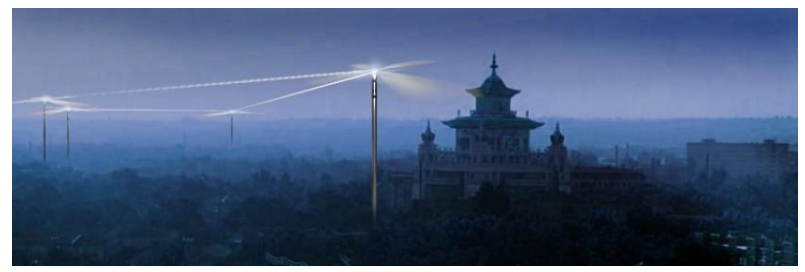

Fig.7. Lighthouse in the city of Elista

In natural environment areas are lighted not only by sunshine but also, when we use simplification, by whole sky what cause that noticed objects are surrounded by light. In artificial lighting vision conditions are completely different. Luminous flux directed into the sky is lost in open space of the sky and value of reflected light, as distinct from close spaces, is negligible. Design of street lighting is not only a matter of light sources type or number, but we must properly select entire equipment (e.g. fittings, the way of supply and protection etc.), furthermore type of lighting pylons and the way of arrangement are also very important issues. Working conditions should by also determined:

- width and mutual location of every part of the street: roadway, pavements, tram tracks

- $\quad$ type of building development (height, density)

- $\quad$ stand density

- traffic infrastructure (tractions, power network, telephone networks) 
The imaginary grid would be a guide for travelers from one monument to another. Figure 8 shows 3D lighting network in the airspace:

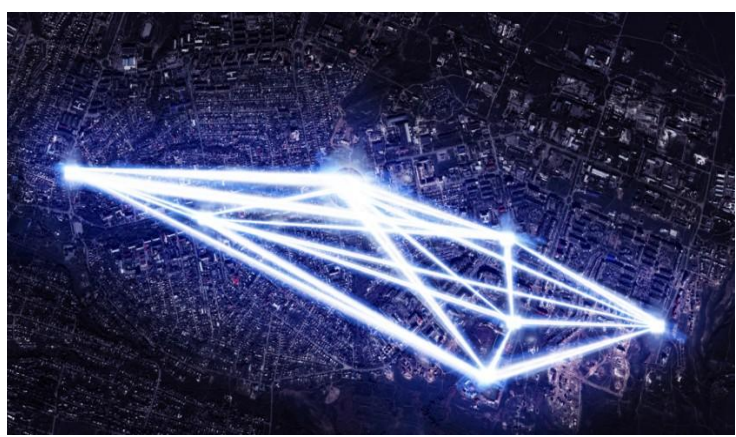

Fig.8. 3D lighting network in the airspace

In this case very important for lighting efficiency is the way of arrangement of light sources. We must remember that lamppost is another obstacle near the roadway and it increases danger for road users. The lampposts arrangement should be designed in such a way that this danger would be minimized. Based on that this project expects focused spot light sources such as LED spotlight, LED projection respectively with $\mathrm{Ra}>60$ and service life: $50000 \mathrm{~h}$ at $70 \%$ luminous flux.

\section{Conclusion}

The aim of this work was to talk about Kalmykia and the identities that are currently little known even in the Russian Federation, and thereby attract tourists. In this thesis I analyzed the Kalmykia traditions and customs, including their special culture differs from other regions of European Russia. Using the survey, I found that the most important sights Kalmykia, and I knew that most major monument is the central churul Kalmykia. After analyzing all the information originated the concept navigation system allowing tourists to become better acquainted with the history and Oirats originality. Tourists have been proposed route that can pass, meet with the sights and thus transfer the entire history from paganism to Buddhism. Implementation of the concept helps tourists to navigate in real space, where the network has prepared a special light beacons with each memorable place. It blends the real with the virtual space, and both are associated with solar energy that radiates from every monument. The navigation system is designed to activate tourism in Kalmykia, helped to maintain and develop our traditions and customs, and started development of the region as a whole.

\section{REFERENCES}

[1] Williams, L.: Russian Life, Vol. 57, No. 3 , May-June 2014

[2] Kulturnyiy turizm, Kalmyikiya [online]. [cit. 2013-12-11]. Dostupné z: http://culttourism.ru/kalmykiya/

[3] Novosti Kalmyikii. Zapiski puteshestvennika o Kalmyikii [online] [cit. 2013-12-11]. http://www.kalmykianews.ru/2009/travel-notes-inkalmykia/

[4] Wikipediya, Kalmyikiya [online]. 2014 [cit. 2013-12-11] http://ru.wikipedia.org/wiki/\%D0\%9A\%D0\%B0\%D0\%BB\%D0\%BC \%D1\%8B\%D0\%BA\%D0\%B8\%D 1\%8F

[5] Turizm i aktivnyiy otdyih, Elista [online]. [cit. 2013-12-11] Dostupné z: http://vetert.ru/rossiya/elista/
[6] V.Dal, vykladovy slovnik zhivogo velikorusskogo yazyika, tom 4, s.569

[7] Zolotaya obitel Buddyi Shakyamuni, Istoriya sozdaniya [online]. [cit. 2013-12-11]. http://khurul.ru/?page_id=41

[8] Wikipedie, Stúpa [online]. 2014 [cit. 2013-12-11]. http://cs.wikipedia.org/wiki/St\%C3\%BApa

[9] Turizm i aktivnyiy otdyh, Buddiyskiy hram, tsentralnyiy hurul «Zolotaya obitel Buddyi Shakyamuni» [online]. 2014 [cit. 2013-1211]. http://vetert.ru/rossiya/elista/sights/173-buddijskij-hramhurul.php

\section{Authors: \\ Anna Maltseva, MgA., Technická univerzita v Liberci, Fakulta textilní, Laboratoř Měření Barevnosti a Vzhledu, Studentská 2,} 46117 Liberec, Czech Republic, e-mail: an.malce@yandex.com

Kermen Bainkharaeva, Ing.,Technical University of Liberec, Faculty of Textile Engineering, Department of Material Science, kermyasha@yandex.com

Aleksandra Pinaeva, Bc.,Technical University of Liberec, Faculty of Art and Architecture, Department of Architecture, pinsky.a.sandra@gmail.com

doc. Ing. Michal Vik, Ph.D., Technická univerzita v Liberci, Fakulta textilní, Laboratoř Měření Barevnosti a Vzhledu, Studentská 2, 46117 Liberec, Czech Republic, e-mail: michal.vik@tul.cz 